\title{
TANGGAPAN MASYARAKAT TERHADAP KETERLIBATAN \\ KAUM PEREMPUAN DALAM POLITIK \\ (SUATU PENELITIAN PADA GAMPONG PANGO RAYA \\ KEC. ULEE KARENG KATO BANDA ACEH)
}

\author{
Halik \\ Program Studi Pendidikan Pancasila dan Kewarganegaraan \\ Universitas Jabal Ghafur Sigli
}

\begin{abstract}
ABSTRAK
Keterlibatan kaum perempuan dalam politik sesungguhnya merupakan sebuah proses yang perjalanannya sangat panjang. Sebab itu tidak lepas dari adanya paham patriarki yang melahirkan konstruksi sosial dan kultural, dengannya menempatkan kaum laki-laki pada posisi yang superior dan kaum perempuan pada posisi yang lebih lemah. Dalam pemahaman tersebut, menjalar kesegala bidang termasuk dalam pembagian kerja, dalam hal ini kerja publik dan domestik. Pada ranah politik merupakan dunianya laki-laki sedangkan pada ranah domestik sudah merupakan dunianya perempuan. Oleh sebab itu lahirlah persepsi yang dialamatkan kepada kaum perempuan tidak mampu menduduki pada ranah politik apa lagi sampai menjadi pemimpin pada lembaga. Tentu saja pernyataan ini dipertajam dengan adanya doktrin bahwa kaum perempuan tidak pantas menjadi pemimpin walaupun ia pandai. Sebab itu latar belakang ini peneliti sangat tertarik untuk meneliti tentang tanggapan masyarakat terhadap keterlibatan kaum perempuan dalam politik. Adapun tujuan penelitian ini, mengetahui tanggapan masyarakat terhadap keterlibatan kaum perempuan dalam politik, mengetahui hambatan apa saja yang dialami kaum perempuan dalam politik, penelitian ini dilaksanakan di Gampong Pango Raya Kecamatan Ulee Kareng Kota Banda Aceh. Pendekatan metode deskriptif-kualitatif yang digunakan, instrumen pengumpulan data melalui observasi dan indeef interview. Populasi penelitian ini masyarakat Gampong Pango Raya Kecamatan Ulee Kareng Banda Aceh, menggunakan sampel sebanyak 40 orang yang terdiri dari 20 orang laki-laki dan 20 orang perempuan dengan model purpose sampling. Adapun hasil penelitian yang diperoleh menunjukan bahwa masyarakat Gampong Pango Raya Kecamatan Ulee Kareng Banda Aceh sangat mendukung keikutsertaan kaum perempuan dalam politik. Keikutsertaan kaum perempuan dalam berpolitik akan sangat membantu dalam menyuarakan aspirasi kaum perempuan lainnya, walaupun terdapat sejumlah kendala yang dialami misalnya bagi mereka yang sudah menikah tidak mendapatkan izin dari suami, selain itu tingkat pendidikan yang rendah, lemahnya dukungan dari pihak keluarga, dan persepsi negatif masyarakat terhadap keikutsertaan kaum perempuan dalam politik serta kaum perempuan itu sendiri minatnya rendah.
\end{abstract}

Kata kunci: Masyarakat, Perempuan, Politik.

\section{Latar Belakang Masalah}

Dewasa ini perkembangan kehidupan masyarakat Indonesia pasca reformasi 20 tahun lalu berkembang sangat signifikan. Hal ini dapat disadari dengan munculnya berbagai perkem-bangan baru yang membawa perubahan secara signifikan dalam tatanan kehidupan masyarakat. Perubahan mendasar dan mencolok dapat dilihat dari sejumlah persepsi yang disalurkan melalui ranah dunia politik. Oleh sebab itu, salah satu perkembanganyang dihadapi oleh masyarakat dalam bidang politik adalah tampilnya kaum perempuan dalam panggung politik. Seperti kita ketahui bahwa dalam dunia politik yang awalnya lebih dominan adalah laki-laki yang mengapresiasikan pandangan politiknya 
dalam masyarakat, sebab dalam ketentuan perundang-undangan yang baru, kaum perempuan dapat ikut serta terjun dalam dunia perpolitikan. Asshiddiqie (2015:105), mengemukakan bahwa masalah pendidikan adalah masalah yang sangat penting. Sebagaimana tujuan negara dalam pembukaan UUD 1945 yang menyebutkan bahwa tujuan bangsa Indonesia adalah untuk mencerdaskan anak bangsa, salah satunya melalui sektor pendidikan. Peranan kaum perempuan sebagai bagian dari warga masyarakatyang dapat dilihat sebagai penopang dalam hidup berpolitik.

Untuk itu Aceh adalah salah satu provinsi dalam wilayah Negara Kesatuan Republik Indonesia yang mempunyai kedudukan khusus dengan diberikannya otonomi yang bersifat seluas-luasnya. Implementasi pen-erapan otonomi dapat dilihat dari berlakunya UU No. 11 Tahun 2006 Tentang Pemerintahan Aceh. Dalam UU tersebut Pasal 75, menye-butkan bahwa perempuan dapat terlibat lang-sung dalam dunia politik dengan perwakilan sebanyak $30 \%$, dan perempuanjuga dapat ikut dalam kepengurusanpartaidenganketer-wakilannya sebayak $30 \%$. Tidak hanya itu, data $30 \%$ keikutsertaan perempuan juga berlaku dalam pendirian dan kepengurusan partai politik di tingkat pusat maupun daerah. Di samping itu dalam pendirian sebuah partai politik harus menyerap sedikitnya 30\% kaum perempuan. Pernyataan ini dipertegas lagi dalam pasal 2 UU partai politikno. 2 tahun 2008 tentang pem-bentukan partai politik. Dimana dalam UU inijuga menyebutkan bahwa pendiri dan pembentukan partai politik menyertakan $30 \%$ keterwakilan perempuan.

Demikianjuga, dalam UndangUndang Nomor 7 Tahun 2017 tentang Pemilihan Umum,Undang-Undang ini membuka peluang bagi kaum perempuan melalui Pasal 65 Ayat 1 yang menyebutkan bahwa partai politik" dapat" mencalonkan $30 \%$ perempuan sebagai calon anggota legislatif. Oleh sebab itu, UU No.12 Tahun 2003 tentang Pemilihan Umum kemudian disempurnakan menjadi UU No.10 Tahun 2008 tentang Pemilihan Umum yang menjadi landasan hukum pemilihan umum 2009. Pasal 53 UU No.10 Tahun 2008 kembali memuat kuota $30 \%$ calon legislatif perempuan, ditambah dengan pasal 55 ayat 2 yang mencantumkan sistem zipper atau di setiap tiga orang bakal calon terdapat sekurang-kurangnya satu orang perempuan.

Adanya ruang inilah sebenarnya yang menjadi awal bangkitnya perjuangan bagi partisipasi perempuan dalam bidang politik. Dan sekiranya proses ini akan menjadi bagian penting dari perubahan. Maka diharapkan agar anggota legislatif yang peka terhadap problem-problem perempuan, akan membantu untuk peningkatan kesejahteraan hidup kaum perempuan nantinya. Karena masih banyak agenda perempuan yang harus diperjuangkan.Persoalan kemiskinan, kesehatan, pendidikan perempuan dan kekerasan terhadap perempuan harus tetap diperjuangkan jalan keluarnya. Sebenarnya keterwakilan perempuan diparlemen dapat dikatakan kebutuhan yang mendesak. Hal ini dapat dilihat nyata dari target $30 \%$ calon legeslatif perempuan yang belum tercapai. Dukungan perempuan diparlemen harus pula diikuti dengan dukungan partai politik terhadap akses perempuan didalamnya agar suara yang berpihak pada perempuan lebih banyak terdengar.

Kesadaranperempuandalam kehidupan politikdanbagaimana menyuarakan kepenting-an mereka menjadi hal yang sangat dibutuhkan. Untuk itulah masyarakat perempuan dituntut untuk bisa berpartisipasi aktif di dalam ranah politik, baik tingkat lokal maupun nasional. Keterlibatan politik perempuan khususnya dalam kepengurusan organisasi sosial politik pada DPD tiap provinsi sampai saat ini masih relatif sedikit bila dibandingkan dengan laki-laki. Struktur kepengurusannya masih tetap didomi-nasi oleh kaum laki-laki. Hal ini disebabkan karena kaum perempuan belum memahami hak-hak mereka dalam bidang politik, termasukbagaimana cara menyuarakan kebutuhan mereka. Sehingga dengan demikian memberikan indikasi bahwa perempuan memiliki minat relatif kecil dalam struktur politik formal. Hal ini tentu 
dapat menimbulkan berbagai macam tanggapan yang keluar dari masyarakat terhadap kualitas perempuan dalam politik. Keraguan terhadap perempuan dalam berpolitik juga menjadi persoalan utama, meskipun disisi lainnya dapat dilihat sebagai kemajuan dalam membawa perubahan.

Berdasarkan permasalahan tersebut di atas, peneliti sangat tertarik untuk melaksanakan penelitian yang diberi tema: Tanggapan Masyarakat Terhadap Keterlibatan Kaum PerempuanDalam Politik Pada Gampong Pango Raya Kecamatan Ulee Kareng Kota Banda Aceh.

\section{Rumusan Masalah}

Berdasarkan permasalahan tersebut di atas, maka dapat dirumuskan beberapa masalah sebagai berikut:

1. Bagaimana tanggapan masyarakat Gampong Pango Raya Kecamatan Ulee Kareng Banda Aceh terhadap keterlibatan kaum perempuan dalam berpolitik?

2. Apa saja kendala-kendala yang dialami kaum perempuan dalam berpolitik di Gampong Pango Raya Kecamatan Ulee Kareng Banda Aceh?

\section{Tujuan Penelitian}

Adapun tujuan penelitian ini yang ingin dicapai adalah sebagai sebagai berikut:

1. Untuk mengatahui tanggapan masyarakat Gampong Pango Raya Kecamatan Ulee Kareng Banda Aceh terhadap keterlibatan kaum perempuan dalam berpolitik.

2. Untuk mengetahui kendala-kendala yang alami kaum perempuan dalam berpolitik di Gampong Pango Raya Kecamatan Ulee Kareng Banda Aceh.

\section{Manfaat Penelitian}

Adapun manfaat yang diharapkan dari hasil penelitian ini adalah sebagai berikut:

1. Untuk menambah pengetahuan bagi peneliti terkait tanggapan masyarakat terhadap keterlibatan kaum perempuan berpolitik serta akan menjadi bahan rujukan awal bagi penelitian lanjutan.
2. Untuk memperkaya khazanah keilmuan umum dan menjadi literatur baru bagi kepustakaan Universitas Jabal Ghafur Sigli.

3. Untuk menjadi masukan bagi kaum perempuan, khususnya yang ikut serta berkecimpung dalam dunia politik.

\section{Landasan Teoritis}

1. Pengertian Tanggapan Masyarakat

Adalah manusia merupakan makhluk yang memiliki keinginan untuk menyatu dengan sesamanya serta alam lingkungan di sekitarnya, menggunakan pikiran, naluri, perasaan, keinginan dan sebagainya. Manusia memberi reaksi dan melakukan interaksi dengan lingkungannya. Pola interaksi sosial dihasilkan oleh hubungan yang berkesinambungan dalam suatu masyarakat. Istilah masyarakat berasal dari bahasa arab "syaraka" yang berarti ikut serta, berpartisipasi, atau "musyaraka" yang berarti saling bergaul. Di dalam bahasa inggris dipakai istilah "society", yang sebelumnya berasal dari bahasa latin "socius", berarti "kawan". Masyarakat berasal dari kata musyarak (arab), yang artinya bersama-sama, kemudian berubah menjadi masyarakat, yang artinya berkumpul bersama, hidup bersama dengan saling berhubungan dan saling mempengaruhi, selanjutnya mendapatkan kesepakatanmenjadi masyarakat (Indonesia). Masyarakat adalah sekumpulan individu (manusia) yang terikat oleh pemikiran, perasaan dan system (aturan) yang sama. Masyarakat juga dapat diartikan sebagai sejumlah manusia yang terikat oleh suatu kebudayaan yang mereka anggap sama meskipun memiliki latar belakang kepribadian yang berbeda dimana, didalamnya adanya unsur kekeluargaan, persatuan, kesatuan dan tanggungjawab. Steinmentz, seorang ahli sosiologi Belanda memberikan batasan tentang masyarakat sebagai kelompok manusia yang terbesar yang meliputi pengelompokan-pengelompokan manusia yang lebih kecil yang mem-punyai penghubungerat dan teratur pengertian ini menunjukkan bahwa suatu 
masyarakat men-cakup kelompok manusia yang kecil sampai dengan yang sangat besar, termasuk negara.

Menurut Basrowi (2015:38-40), pengertian masyarakat menurut para ahli: a) Menurut John Lewis Gillin dan John Philip Gillin bahwa masyarakat itu adalah kelompok manusia yang terbesar yang mempunyai kebiasaan, tradisi, sikap dan perasaan persatuan yang sama. Masyarakat itu meliputi pengelom-pokan yang lebih kecil. Pengertian ini menunjukkan bahwa masyarakat itu meliputi kelompok manusia yang kecil sampai dengan kelompok manusia dalam suatu masyarakat yang sangat besar, seperti suatu Negara. Seperti diketahui, suatu Negara juga memiliki kebiasaan, tradisi, sikap, dan perasaan persatuan yang sama dan keteraturan. b) Menurut Auguste Comte (1896) mengatakan, bahwa masyarakat adalah kelompok-kelompok makhluk hidup dengan realita-realita baru yang berkembang menurut pola perkembangan yang tersendiri. Masyarakat dapat membentuk kepribadian yang khas bagi manusia, sehingga tanpa adanya kelompok, manusia yang dengan atau sendirinya bertalian secara golongan besar atau kecil dari beberapa manusia, yang dengan atau sendirinya bertalian secara golongan dan mempunyai pengaruh kebatinan satu sama lain. c) Koentjaraningrat (1980:160), merumuskan definisi masyarakat sebagai berikut: masyarakat adalah kesatuan hidup manusia yang berinteraksi menurut suatu sistem adat istiadat tertentu yang bersifat kontinu dan yang terikat oleh suatu rasa identitas bersama dan d) Menurut Selo Sumardjan masyarakat adalah orang-orang yang hidup bersama dan menghasilkan kebudayaan. Jadi, Masyarakat adalah sejumlah manusia yang merupakan satu kesatuan golongan yang berhubungan tetap dan mempunyai kepentingan yang sama. Seperti; sekolah, keluarga, perkumpulan, Negara semua adalah masyarakat. Tanggapan adalah bayangan atau kesan dari pada apa yang pernah kita amati. Tanggapan masyarakat adalah suatu bentuk penilaian yang diberikan oleh masyarakat terhadap sesuatu yang ingin dinilai. Menurut Arikunto; menilai adalah mengambil keputusan terhadap sesuatu dengan baik, penilaian yang bersifat kuantitatif. Sedangkan penilaian menurut Mahrens adalah suatu pertimbangn professional atau proses yang memungkinkan seseorang untuk membuat suatu pertimbangan mengenai nilai sesuatu.

2. Pengertian Perempuan

Perempuan adalah lawan jenis dari laki-laki yang memiliki peran, tingkah laku, emosional dan secara biologis memiliki perbe-daan dengan laki-laki seperti, perbedaan bentuk tubuh dan lain sebagainya. Selain itu perempuan juga dapat diartikan sebagai wanita yang juga berarti kaum hawa, seseorang yang mempunyai watak dan sifat yang lembut dan wajib dilindungi oleh laki-laki.

3. Pengertian Politik.

Bahwa secara etimologis, politik berasal dari kata Yunani polis yang berarti kota atau negara kota. Kemudian arti itu berkembang menjadi polites yang berarti warganegara, politeia yang berarti semua yang berhubungan dengan negara, politika yang berarti pemerintah-an negara dan politikos yang berarti kewarga-negaraan. Aristoteles (384-322 SM) dapat dianggap sebagai orang pertama yang memperkenalkan kata politik melalui pengamatannya tentang manusia yang ia sebut zoon politikon. Dengan istilah itu ia ingin menjelaskan bahwa hakikat kehidupan sosial adalah politik dan interaksi antara dua orang atau lebih sudah pasti akan melibatkan hubungan politik. Aristoteles melihat politik sebagai kecenderungan alami dan tidak dapat dihindari manusia, misalnya ketika ia mencoba untuk menentukan posisinya dalam masyarakat, ketika ia berusaha meraih kesejahteraan pribadi, dan ketika ia berupaya memengaruhi orang lain agar menerima panda-ngannya. Aristoteles berkesimpulan bahwa usaha memaksimalkan kemampuan individu dan mencapai bentuk kehidupan sosial yang tinggi adalah melalui interaksi politik dengan orang lain. Interaksi itu terjadi di 
dalam suatu kelem-bagaan yang dirancang untuk memecahkan konflik sosial dan membentuk tujuan negara. Dengan demikian kata politik menunjukkan suatu aspek kehidupan, yaitu kehidupan politik yang lazim dimaknai sebagai kehidupan yang menyangkut segi-segi kekuasaan dengan unsur-unsurnya: negara (state), kekuasaan (power), pengambilan keputusan (decision making), kebijakan (policy), dan pembagian (distribution) atau alokasi (allocation).

Pada umumnya dapat dikatakan bahwa politik (politics) adalah bermacam-macam kegiatan dalam suatu sistem politik (atau negara) yang menyangkut proses menentukan tujuan-tujuan dari sistem itu dan melaksanakantujuan-tujuan itu. Pengambilan keputusan (decision making) mengenai apakah yang menjadi tujuan dari sistem politik itu menyangkut seleksi terhadap beberapa alternatif dan penyusunan skala prioritas dari tujuan-tujuan yang telah dipilih. Sedangkan untuk melaksanakan tujuan-tujuan itu perlu ditentukan kebijakankebijakan umum (public policies) yang menyangkut pengaturan dan pembagian (distribution) atau alokasi (allocation) dari sumber-sumber (resources) yang ada. Untuk bisa berperan aktif melaksanakan kebijakankebijakan itu, perlu memiliki kekuasaan (power) dan kewenangan (authority) yang akan digunakan baik untuk membina kerjasama maupun untuk menyelesai-kan konflik yang mungkin timbul dalam proses itu. Cara-cara yang digunakan dapat bersifat meyakinkan (persuasive) dan jika perlu bersifat paksaan (coercion). Tanpa unsur paksaan, kebijakan itu hanya merupakan perumusan keinginan (statement of intent) belaka. Politik merupakan upaya atau cara untuk memperoleh sesuatu yang dikehendaki. Namun banyak pula yang beranggapan bahwa politik tidak hanya berkisar di lingkungan kekuasaan negara atau tindakan-tindakan yang dilaksanakan oleh peng-uasa negara. Dalam beberapa aspek kehidupan, manusia sering melakukan tindakan politik, baik politik dagang, budaya, sosial, maupun dalam aspek kehidupan lainnya. Demikianlah politik selalu menyangkut tujuan-tujuan dari seluruh masyarakat (public goals) dan bukan tujuan pribadi seseorang (private goals). Politik menyangkut kegiatan berbagai kelompok, termasuk partai politik dan kegiatan-kegiatan perseorangan (individu).

4. Partisipasi Politik

Partisipasi merupakan salah satu aspek penting dalam sistim demokrasi, bahkan yang mendasari demokrasi adalah nilai-nilai partisi-pasi. Karena partisipasi adalah keikutsertaan warga negara biasa dalam mem-pengaruhi proses pembuatan dan pelaksanaan keputusan politik. Handoyo Eko (2013: 248-250) Partisipasi politik adalah kegiatan sukarela dari warga masyarakat melalui mana mereka mengambil bagian dalam proses pemilihan penguasa baik secara langsung atau tidak langsung dalam proses pembentukan kebijakan umum. Hungtington dan Nelsen (1994 : 6) berpendapat bahwa : partisipasi politik merupa-kan kegiatan warga Negara yang bertindak sebagai pribadi-pribadi dengan maksud untuk mempengaruhi pembuatan keputusan pem-erintah, dan partisipasi dapat bersifat individual atau kelompok. Wiener dan Huntigton (1994: 10) menekankan sifat sukarela dari partisipasi dan mengemukakan "menjadi anggota organi-sasi atau menghadiri rapat umum atas perintah pemerintah, tidak termasuk partisipasi politik". Dari pengertian ini maka, partisipasi dalam bentuk apapun yang dilakukan oleh para aktivis perempuan pada hakekatnya adalah usaha menggali dan memberdayakan potensi-potensi yang dimiliki oleh perempuan. Secara umum partisipasi tidak hanya pada bidang politik akan tetapi dalam segala bidang kehidupan perempuan mempunyai hak dan kewajibannya untuk ikut serta atau berpartisipasi aktif, hanya saja karena selama ini terjadi kesenjangan antara kaum laki-laki dan perempuan yang diakibatkan oleh produk-produk kebijakan yang bias 
gender. Sehingga dibutuhkan perjuangan keras dan holisticdari segenap perempuan dalam segala lini, terlebih pada lini politik, karena sangat berpengaruh terhadap produk kebijakan.

Lester dalam bukunya "Political Participation", menyebutkan adanya dua orientasi dalam partisipasi politik berhubungan dengan proses politik yaitu: partisipasi politik yang berhubungan pada output proses politik (disebut partisipasi pasif) dan pada input proses politik (disebut partisipasi aktif), dimana aktivitas individu atau kelompok yang berkenaan dengan masukan-masukanproses pembuatan kebijakan. Dalam partisipasi politik berlaku proses-proses politik yang harus difahami dan diikuti, baik laki-laki atau perempuan. Yang dikatakan oleh Easton, proses politik adalah merupakan interaksi di antara lembaga-lembaga pemerintahan kelompokkelompok sosial. Hal ini menunjukkan tidak hanya aktivitas yang ada pada tingkat elit tetapi melihat sudut pandang yang lebih pluralistic yang menyertakan analisis pada aktivitas-aktivitas berbagai kelompok yang terorganisir di luar pemerintahan dengan memberikan penekanan pada individuindividu, kepentingan-kepentingan bersama dan nilai normatif. Sehinga berpartisipasi tidak sekedar ikut - ikutan tanpa tujuan dan arah yang jelas bagi setiap anggota akan tetapi dalam proses partisipasi keterlibatan secara aktif mental, emosi dan prilaku untuk memperoleh sesuatu yang diharapkan menjadi bagian yang penting.

\section{Metodologi Penelitian}

1. Pendekatan dan Jenis Penelitian.

Penelitian ini merupakan penelitian deskriptif kualitatif, yaitu: suatu penelitian yang menggambarkan suatu fenomena yang terjadi dalam masyarakat. Sudjana (1989:52) men-jelaskan bahwa" Metode deskriptif digunakan apabila penelitian bertujuan untuk menjelaskan dan menafsirkan suatu peristiwa atau kejadian pada masa sekarang. Selain itu menurut Surahmad (1980) metode deskriptif adalah menunjukkan dan menafsirkan data yang ada, misalnya tentang situasi yang diambil suatu hubungan dengan kesehatan, pandangan, sikap yang nampak atau tentang suatu proses yang sedang berkerja, kelainan yang sedang muncul, kecenderungan yang sedang nampak, perten-tangan yang sedang meruncing dan sebagainya.

2. Populasi dan Sampel.

Populasi merupakankeseluruhan objek dari suatu penelitian. Dalam suatu penelitian yang tersusun dan terencana dengan baik dan sistematis, penetapan populasi merupakan suatu keharusan yang harus diperhatikan di dalam suatu penelitian. Kesimpulan dari suatu pen-elitian biasanya tidak hanya dibatasi pada orang-orang yang diselidiki, tetapi juga berlaku pada orangorang tidak termasuk menjadi subjek peneliti dan inilah yang dinamakan dengan populasi. Adapun sampel, menurutHadi (1989:70) bahwa:" sebagai individu yang diselidiki tersebut disebut sampel atau contoh, sedangkan semua individu untuk siapa kenyataan-kenyataan diperoleh dari sampel itu hendak digeneralisasikan disebut populasi." Dengan demikian yang menjadi populasi dalam penelitian ini adalah seluruh masyarakat yang bertempat tinggal di Gampong Pango Raya Kecamatan Ulee Kareng Banda Aceh yang sudah memiliki hak pilih dengan jumlah 1400 orang. Sedangkan penelitian ini ditetapkan sample sebanyak 40 orang masyarakat yang sudah mempunyai hak pilih, yang diambil secara purposive sampling yang diperkirakan dapat mewakili populasi dan dianggap lebih resprentatif. Seperti yang dikatakan Surahmad (1984:89)," sampel merupakan bagian dari populasi yang menjadi subjek penelitian dan yang diperkirakan dapat mewakili populasi secara seluruhan, jika populasinya banyak, maka pengambilan sampel dilakukan dengan tektis yang tepat dan jika populasinya sedikit, maka pengambilan sampel disarankan seluruhnya, dengan demikian disebut penelitian populasi".

3. Tehnik Pengumpulan Data 
Untuk mendapatkan data yang valid peneliti menggunakan teknik: a) Observasi, menurut Narbuko (2003:70) observasi merupakan alat pengumpulan data yang dilakukan dengan mengamati dan mencatat secara sistematis gejala-gejala yang diselidiki, dengan demikian penulis dapat menghasilkan data yang valid, dan b) Wawancara, selanjutnya Narbuko mengatakan bahwa wawancara adalah suatu proses tanya jawab dalam penelitian yang berlangsung secara lisan, dimana dua orang atau lebih bertatap muka mendengarkan secara langsung informasi-informasi atau keterangan-keteranngan tertentu. Dalam hal ini penulis lakukan dengan pihak yang terkait serta pihak yang berhubungan dan berkompeten untuk mendukung hasil penelitian ini.

4. Lokasi Penelitian.

Penelitian ini dilaksanakan pada Gampong Pango Raya Kecamatan Ulee Kareng Banda Aceh.

5. Metode Pengolahan Data.

Adapun data yang diperoleh dengan menggunakan metode observasi dan wawancara, data tersebut diolah dan dianalisis dengan menggunakan rumusan analisis naratif komparatif, yaitu: analisis dengan menggunakan kata-kata yang logis setelah mendapat data dilapangan dan setelah diolah, kemudian data tersebut dipadukan dengan teori yang telah dikemukakan oleh para ahli tersebut di atas. Menurut Arikunto (2003:236) istilah komparatif adalah menemukan persamaanpersamaan dan perbedaan-perbedaan tentang benda-benda, orang, prosedur kerja, ide dan lain-lain. Dapat juga membandingkan persamaan pandangan dan perubahanperubahan pandangan orang, group, atau negara terhadap negara, terhadap kasus, terhadap peristiwa atau terhadap ide-ide, dalam kaitan dengan penelitian ini, hasil olahan dari penelitian ini akan mendeskripsikan tentang tanggapan masyarakat Gampong Pango Raya Kecamatan Ulee Kareng Banda Aceh terhadap keterlibatan kaum perempuan dalam politik dan kendala-kendala yang dialami kaum perempuan dalam berpolitik.

\section{Hasil Penelitian}

Sehubungan dengan penelitian tanggapan masyarakat terhadap keterlibatan kaum perempuan dalam politik yang berfokus pada masyarakat Gampong Pango Raya Kota Banda Aceh, dapat disajikan data yang terkumpul melalui wawancara sebagai berikut: data yang diperoleh dapat dijelaskan bahwa responden diambil dari dua jenis kelamin yaitu, 20 orang laki-laki dan 20 orang perempuan. Dapat di-katakan bahwa sesuai dengan teori. Dilihat dari sudut sampelnya, maka sesuai dengan mekanisme random sampling. Dalam melaku-kan penelitian, peneliti diundang oleh kepala desa untuk melakukan wawancara kepada warganya pada saat desa tersebut melakukan aktivitas bersama. Selain itu peneliti juga melakukan wawancara dengan mendatangi rumahrumah warga atau penduduk, kios serta Masjid yang ada di daerah tersebut. Berikut ini merupakan petikan wawancara masyarakat yang bertempat tinggal di Gampong Pango Raya Kecamatan Ulee Kareng berkenaan dengan tanggapan masyarakat terhadap keterlibatan kaum perempuan dalam politik.

1) Pada saat peneliti mewawancarai responden dengan menanyakan pengetahuan mereka tentang politik, masyarakat mulai terlihat ketakutan. Sebagian dari responden langsung mengatakan bahwa mereka tidak mau diwawancarai. Namun ada jugasebagian masyarakat yang bersedia untuk diwawan-carai. Mereka yang enggan untuk diwawan-carai ternyata merasa takut membicarakan politik. Mereka mengatakan bahwa mereka takut ditangkap kalau membicarakan politik. Hal ini diketahui setelah peneliti menanyakan alasan mereka untuk tidak mau diwawancarai. Namun setelah peneliti menjelaskan bahwa hasil wawancara ini hanya akan dicantumkan dalam skripsi peneliti dan tidak ada 
kaitannya dengan pihak lainnya maka, masyarakat mulai bersedia untuk diwawan-carai.Berdasarkan hasil wawancara peneliti dengan responden dapat disimpulkan bahwa hampir ratarata masyarakat Gampong Pango Raya Kecamatan Ulee Kareng tahu tentang politik. Hal ini dapat dilihat dari hasil wawancara peneliti dengan responden, dari 40 orang masyarakat yang dijadikan sampel ada 4 orang yang tidak tahu sama sekali tentang politik. Mereka umumnya tidak melanjutkan lagi pendidikannya kejenjang yang lebih tinggi dan yang tidak punya kegiatan lain setelah menyelesaikan pendidikannya ataupun tidak menyelesaikan pendidikannya. Sedangkan masyarakat yang tahu tentang politik adalah mereka yang memiliki pekerjaan sebagai PNS, swasta, wiraswasta dan IRT. Menurut mereka politik itu adalah suatu proses, taktik atau cara yang digunakan oleh seseorang untuk memperoleh kekuasaan. Karena dengan kekuasaan inilah mereka yang duduk dipemerintahan dan akan memperjuangkan nasib rakyatnya, tanpa adanya kekuasaan, seseorang tidak dapat berbuat apa-apa.

2) Responden terlihat sangat nyakin dengan jawaban yang diberikannya pada saat peneliti menanyakan siapa saja menurut responden yang berhak terlibat dalam politik. Hasil penelitian menggambarkan bahwa menurut masyarakat yang ada di Gampong Pango Raya semua orang berhak terlibat dalam politik, baik itu laki-laki maupun perempuan tanpa ada pengecualian, asalkan orang tersebut sudah cukup umur, mengerti tentang politik, memiliki harapan dan tujuan untuk membangun masyarakat kedepan, memiliki wawasan yang luas, mau memperhatikan rakyat, memperjuangkan rakyat dan menampung aspirasi rakyat.

3) Peneliti melihat responden sangat bangga dalam menyebutkan jumlah perempuan yang terlibat dalam politik di Gampong Pango Raya. Mereka terlihat sangat bersemangatdalam menceritakan kegiatan yang diadakan oleh mereka (kaum perempuan) yang terlibat dalam politikuntuk masyarakat yang ada di Gampong Pango Raya. Dari responden, penulis mendapatkan informasi bahwa kaum perempuan Gampong Pango Raya ada 10 sampai 20 orangyang terlibat dalam politik. Tiga di antaranya pernah mencalonkan diri menjadi caleg namun tidak terpilih. Satu dari PPP dan dua dari PKS. Sedangkan lainnya hanya sebagai anggota partai. Seperti partai PPP, PKS, PAN dan partai Demokrat. Anggotaamggota partai inilah yang banyak terjun ke dalam masyarakat untuk mengadakan kegiatan-kegiatan seperti mengajari masyarakat memasak dan menjahit. Dan ini dilakukan hanya pada saat hampirhampir pemilu saja. Setelah itu, tidak ada lagi kegiatan semacam ini.

4) Dari hasil penelitian yang dilakukan penulis menunjukkan bahwa, menurut pendapat masyarakat Gampong Pango Raya akan sangat bagus apabila ada perempuan yang ikut berkecimpung dalam dunia politik. Hal ini sangat membantu kaum perempuan pada umumnya untuk menyuarakan aspirasi kaum perempuan lainnya. Selain untuk menambah wawasan perempuan itu sendiri, dengan adanya perempuan yang terlibat dalam dunia politik juga akan memperlihatkan kesetaraan gender antara laki-laki dan perempuan. Sehingga tidak ada lagi perbedaan antara laki-laki dan perempuan dimata masyarakat. Apalagi kalau perempuan tersebut bisa membawa suatu perubahan bagi masyarakatnya. Meskipun para responden menjawab demikian, namun ada 2 orang responden khususnya kaum laki-laki terlihat kurang setuju perempuan ikut terlibat dalam politik. Hal ini dapat dilihat dari jawaban mereka yang mengatakan bahwa bolehboleh saja perempuan ikut berpolitik asalkan tidak melupakan kewajibannya sebagai istri dan sebagai ibu bagi anakanaknya. 
5) Dari hasil penelitian yang dilakukan oleh penulis menunjukkan bahwa, menurut masyarakat Gampong Pango Rayaperan perempuan di bidang politik masih sangat kurang. Hal ini bisa dilihat dari jatah yang diberikan sebanyak $30 \%$ hanya beberapa persen saja yang terpenuhi. Buktinya dapat dilihat dari banyaknya kaum perempuan yang mencalonkan diri sebagai caleg namun tidak terpilih di dalam pemilu. Selain itu, masyarakat lebih percaya bahwa lakilaki lebih baik menjadi pemimpin dibandingkan perempuan. Sehingga muncul persepsi bahwa perempuakesempatann hanya pantas ada dirumah untuk mengurus keluarganya. Responden perempuan terlihat sangat kecewa dengan keadaan politik sekarang. Meskipun jatah untuk perempuan telah diberikan sebanyak $30 \%$, tetap saja lebih banyak kaum lakilaki yang terpilih dalam pemilu. Menurut mereka hal ini sangatlah tidak adil bagi kaum perempuan.

6) Dari hasil penelitian menunjukkan bahwa ada beberapa factor yang mendorong perempuan ikut terlibat dalam politik. Faktor-faktor tersebut antara lain:

a. Faktor social,seperti pergaulan. Pergaulan perempuan pada masa sekarang berbeda dengan pergaulan perempuan pada zaman dahulu. Pergaulan perempuan pada zaman sekarang sudah lebih maju dibandingkan pada zaman dahulu sehingga, hal inilah yang mendorong perempuan untuk menunjukkan kepada masyarakat bahwa mereka juga mampu melakukan sesuatu hal yang dapat memberikan suatu pencerahan atau perubahan bagi masyarakat.

b. Faktor ekonomi. Perempuan ikut terlibat dalam politik karena mereka memiliki perekonomian yang cukup sehingga mereka dapat melakukan sesuatu. Seperti halnya mencetak spanduk, baju dan membuat kampaye didaerah-daerah.

c. Faktor pendidikan, mereka ingin mengaplikasikan ilmu yang sudah ada dan mengembangkan kemampuan mereka di bidang yang mereka kuasai.

d. Faktor gender, dalam artian perempuan juga memiliki hak yang sama dengan laki-laki. Jadi tidak ada lagi perbedaan hak antara kaum perempuan dan kaum laki-laki. Karena pada kenyataannya mereka juga ada yang mempunyai kebutuhan dan potensi yang sama dalam dunia politik.

e. Faktor lingkungan, keadaan masyarakat yang memprihatinkan sehingga memicu seseorang ingin melakukan perubahan untuk masyarakatnya.

f. Faktor kesejahteraan perempuan, dimana selama ini kesejahteraan perempuan belum semua terpenuhi.

g. Faktor turun temurun, misalnya dalam keluarga selalu ada yang ikut berkecimpung dalam dunia politik.

7) Dari hasil penelitian dapat dirumuskan beberapa alasan mengapa kaum perempuankurang relative terlibat dalam politik. Alasan-alasan tersebut antara lain kurangnya pengetahuan, perempuan masih belum berani berada didepan pablik, karena pandangan masyarakat yang menganggap kaum perempuan kurang baik ada dalam dunia politik, peran perempuan kurang dominan ketimbang peran laki-laki, kurangnya kesempatan untuk terjun ke dalam dunia politik, karena faktor adat dan budaya kita yang sudah turun temurun cenderung menempatkan posisi perempuan dibelakang laki-laki serta tingginya pemikiran kalau perempuan itu hanya sebagai pengurus rumah tangga saja.

8) Dari hasil penelitian menunjukkan bahwa,kendala-kendala yang 
menghambat perempuan ikut berpolitik adalah bagi mereka yang sudah menikah tidak mendapatkan izin dari suami, tingkat pendidikan yang rendah, tidak adanya dukungan dari pihak keluarga maupun lingkungannya, kurang adanya kesempatan, pandangan masyarakat yang tidak baik terhadap perempuan yang ikut berkecimpung dalam dunia politik serta rendahnya minat dari perempuan itu sendiri. Beberapa orang dari responden juga mengatakan bahwa kebanyakan dari masyarakat melihat politikdari sudut yang kejam. Dalam artian, setiap orang yang terjun kedalam politik kerap kali menghalalkan segala cara untuk dapat memenuhi keinginannya. Sedangkan perempuan itu sendiri sangat identik dengan kelembutan jadi, menurut responden perempuan yang terlibat dalam politik akan menjadi buruk dimata masyarakatnya.

9) Dari hasil penelitian yang dilakukan penulis menunjukkan bahwa adapun cara yang dapat diambil oleh perempuan yang terlibat dalam aktifitas politik dalam mengatur rumah tangga danaktifitas politiknya adalah dengan cara membagi waktu antara keluarga dan politik-nya. Namun tidak tertutup kemungkinan juga bagi perempuan yang berkecimpung dalam dunia politik untuk memperkerjakan orang (pembantu) untuk mengurus rumah dan anaknya. Hal ini kebanyakan terjadi, bahkan mereka yang hanya bekerja di kantor saja banyak yang mempekerjakan orang di rumah-nya. Apa lagi bagi mereka yang terjun ke dalam dunia politik. Namun hampir rata-rata dari responden laki-laki mengatakan hal inilah yang membuat mereka tidak ingin para istrinya terlibat dalam politik. Karena bukan tidak mungkin hal-hal yang tidak diinginkan oleh para suani akan terjadi apabila istri mereka ikut berkecimpung dalam dunia politik. Misalnya saja, karena sibuk mengurus politiknya mereka akan terlambat pulang kerumah. Sehingga lama-kelamaan hubungan antara si ibu dengan si anak akan menjadi semakin jauh. Hal ini disebabkan karena sianak sudah kurang mendapat perhatian dari si ibu.

10) Dari hasil penelitian menunjukkan bahwa keterlibatan kaum perempuan dalam politik pada tahun ini mulai mengalami kemajuan dibandingkan tahun yang lalu. Hal ini dapat diketahui dari responden yang mengatakan bahwa pada tahun yang lalu tidak ada satu perempuan pun ikut terjun dalam dunia politik. Namun pada tahun ini sudah mulai nampak ada kemajuan meskipun pada akhirnya tidak terpilih dan beberapa orang lainnya hanya menjadi anggota dari partai saja. Para responden terlihat senang dengan kemajuan yang terjadi akhir-akhir ini. Sehingga dengan demikian perempuan tidak perlu merasa takut lagi untuk melakukan suatu perubahan, baik itu untuk dirinya sendiri maupun untuk masyarakat sekitarnya.

11) Berdasarkanhasil penelitian menunjukkan bahwa, dukungan keluarga terhadap keterlibatan kaum perempuan dalam dunia politik masih sangat kurang meskipun ada sebagian yang mendukung. Hal ini disebabkan karena kurangnya informasi yang diterima oleh pihak keluarga. Kalau pun ada salah satu anggota keluarga perempuan mereka yang terlibat dalam politik, mereka hanya akan memilihnya saja namun tidak mendukung aktifitasnya. Mereka masih menganggap bahwa berpolitik itu bukan pekerjaan perempuan. Jadi, urusan politik lebih baik diserahkan kepada kaum laki-laki. Karena merekalah yang lebih banyak tahu dan lebih pantas menjadi seorang pemimpin. Responden juga mengatakan bahwa, bagaimana keluarga bisa mendukung anak perempuannya berkecimpung dalam dunia politik. Sementara kenyatannya justru kaum perempuan itu sendiri lebih percaya kepada kaum lakilaki ketimbang kaum perempuan.

12) Fakta lain menunjukkan bahwa perhatian dan konstribusi perempuan yang terlibat dalam politik kepada masyarakat ada namun masih kurang. Biasanya kalaupun ada konstribusi mereka lebih memilih-milih beberapa orang saja, itupun hanya dilaku-kan pada 
saat kampanye-kampanye saja setelah itu tidak ada lagi. Konstribusi lain yang ditunjukan oleh kaum perempuan yang ikut terlibat dalam politik terhadap masyarakat hanyalah berupa keterlibatan mereka dalam pembagian sembako, baju dan kain sarung.

\section{Pembahasan}

Dari hasil penelitian di atas ditemukan deskripsi bahwa pendapat masyarakat Gampong Pango Raya Kecamatan Ulee Kareng Banda Aceh akan sangat baik apabila ada perempuan yang ikut serta berkecimpung dalam dunia politik. Tentu saja hal ini sangat membantu kaum perempuan pada umumnya untuk menyuarakan aspirasi kaum perempuan lainnya. Sejalan dengan hal tersebut juga menambah wawasan perempuan itu sendiri, dengan adanya perempuan yang turut terlibat dalam dunia politik juga akan memperlihatkan kesetaraan gender antara laki-laki dan perempuan tersendiri. Sebab itu tidak ada lagi perbedaan pandangan antara laki-laki dan perempuan di mata masyarakat. Hal ini tampak bagus apabila perempuantersebut mampu membawa suatuperubahan bagi masyarakatnya.

Dewasa ini, politik yang kini tengah menjadi agenda utama dalam wacana masyarakat, telah memberikan warna tersendiri terhadaptatanan pemerintahan di negara kita. Hal ini menjadi daya tarik bagi sekelompok orang termasukkaum perempuan yang ingin berkiprah pada bidang politik. Perempuan sebagai kaum yang dipresentasikan sebagai seorang ibu dan istri, telah dapat membuktikan kemampuannya dalam seluruh kegiatan politik dan pemerintahan di negara ini. Ketertarikan dan keterlibatan perempuan dalam bidang politik saat ini sepertinya telah menjadi suatu keharusan sebab akses, kontrol dan partisipasi perempuan dalam berbagai tindakan maupun dalam pengambilan suatu keputusan merupakan salah satu hak asasi manusia. Hal ini tidak dapat dipungkiri, keter-wakilan perempuan dalam proses pesta demokrasi di negara Indonesia telah mendapat-kan kedudukan yang cukup tinggi, meskipun secara politis posisi mereka masih minoritas.

Adanya beberapa kendala terhadap eksistensi dan kedudukan perempuan di dunia politik menyebabkan sulitnya akses bagi kaum perempuan untuk dapat berkiprah lebih jauh dan mendapatkan kedudukan yang setara dengan kaum laki-laki. Salah satu penyebabnya adalah masalah gender antara perempuan dan laki-laki. Perkembangan posisi dan peran politik wanita Indonesia amatlah lamban. Secara kualitatif, wanita Indonesia belum secara proporsional mempengaruhi dan menentukan proses dan kebijakan politik di Indonesia.

Sebagaimana yang telah diketahui bahwa perjalanan perjuangan keadilan terhadap kesetaraan gender selama ini, telah membukti-kan bahwa politik itu terbuka bagi siapa saja, dan merupakanperwujudan atas kesadaran, kekuatan, dan kemampuan serta adanya kesem-patan untuk mendapatkan semua itu. Siapa pun yang peduli pada keadilan gender selayaknya paham bahwa memberikan" kesempatan" khu-sus bagi perempuan memang perlu, tapi akan kehilangan maknanya jika tak diimbangi dengan usaha tekun membangun kesadarandan kekuatan politik bagi kalangan perempuan.Dengan diberikannya kesempatan dan usaha tekun itulah, akan terjadi transformasi perempu-an Indonesia.

Sehingga dalam hal ini, kaum perempuan dapat menunjukkan kemampuan dan citranya dalam dunia polik, tanpa harus mengesamping-kan identitas dan fungsinya dalam rumah tangga, baik sebagai seorang istri bagi suaminya, maupun sebagai seorang ibu bagi anak-anaknya.

Menurut Prabawati, pada prinsipnya semuaorang setuju bahwa bentuk pemerintahan yang demokratis merupakan bentuk yang paling ideal dan didambakan oleh rakyat. Kata demokrasi sendiri dapat diartikan sebagai se-buah pemerintahan dari, oleh dan untuk rakyat. Dengan demikian, rakyatlah yang memegang kekuasaan tertinggi dalam proses pemerintahan. Pemimpin merupakan pemegang mandat yang harus tunduk kepada suara rakyat melalui wakil-wakil mereka yang duduk dalam kursi legislatif. Untuk itu masyarakat dapat dikatakan demo-kratis jika dalam kehidupannya menghargai hak asasi manusia secara adil dan setara, mengakui untuk

memajukankebebasannya.Penghargaan 
terhadap hak yang adil dan setara tersebut men-cerminkan adanya penghargaan terhadap perbe-daan-perbedaan yang ada, khususnya terhadap kelompok-kelompok minoritas. Karena itu juga mencakup adanya jaminan partisipasi politik bagi semua warga. Partisipasi dalam sistem politik merupakan tugas yang kompleks dan menantang, khususnya bagi sektor-sektor masyarakat yang secara tradisional yang termar-jinalkan. Perempuan mewakili salah satu kelompok yang dirugikan sebagai akibat dari peran-peran yang diterjemahkan secara sosial dan budaya serta hubungan antara laki-laki dan perempuan dalam ranahranah produktif, dan politik.

Sementara kendala-kendala yang meng-hambat perempuan ikut berpolitik adalah bagi mereka yang sudah menikah tidak mendapatkan izin dari suami, tingkat pendidikan yang rendah, tidak adanya dukungan dari pihak keluarga maupun lingkungannya, kurang adanya ke-sempatan, pandangan masyarakat yang tidak baik terhadap perempuan yang ikut berkecimpung dalam dunia politik serta rendahnya minat dari perempuan itu sendiri. Perempuan sebagai salah satu kelompok minoritas sampai saat ini masih berada dalam posisi subordinat dibanding laki-laki. Meskipun secara kuantitatif mereka lebih banyak tetapi hal ini tidak berarti ada jaminan terhadap hak-hak mereka. Faktor budaya merupakan salah satu penghambat bagi perempuan untuk tampil dalam forum publik. Kuatnya peran laki-laki dalam kehidupan publik sangat menentukan setiap keputusan-keputusan yang diambil meskipun itu menyangkut ke-hidupan perempuan. Hal ini menempatkan posisi perempuan semakin termarginalkan, terutama dalam partisipasi politik sematamata karena mereka adalah perempuan. Inilah yang disebut sebagai diskriminasi berbasis gender.

Adapun hambatan yang datang dari diri perempuan adalah budaya patriarki yang sudah mengakar dalam diri seseorang. Ini harus diselesaikan melalui pendidikan kritis dan advokasi. "Hambatan-hambatan tidak datang dari undang-undang dan kultur di masyarakat, tapi juga pelanggaran the right to stand atau hak untuk menjadi kandidat," Selain itu, ketidak-adilan dalam kesempatan pendidikan juga menjadi kendala perempuan masuk dalam dunia politik. Syarat pendidikan kandidat menjadi batu sandungan perempuan terpilih berkecimpung masuk dalam partai politik. Padahal kita tahu, laki-laki dan perempuan memiliki kesenjangan dalam pendidikan. Pendidikan pun bukan jaminan seseorang akan peduli pada masalah kesejahteraan perempuan.

Partisipasi

merupakansalah politikperempuan
saturasyarat terlaksananya demokrasi. Karena tidak ada demokrasi yang sesungguhnya jika masih terdapat pengingkaran kesetaraan antara laki-laki dan perempuan sehingga ber-akibat 'tersingkirnya' perempuan dari gelang-gang politik. Kehidupan demokrasi yang sejati adalah kehidupan dimana semua anggota masyarakat mendapat kesempatan yang sama untuk bersuara dan didengar. Peran politik sangat penting untuk mendorong kebijakan yang berkeadilan sosial, terutama yang berkaitan dengan kehidupan perempuan. Sementara me-lalui kebijakan, hukum dapat berlaku melin-dungi kepentingan kaum perempuan dari ber-bagai bentuk kekerasan baik domestik maupun publik. Seharusnya memikirkan kepentingan masyarakat umum dimana demokrasi sebagai sarana pencapaian kekuasaan.

\section{Kesimpulan.}

1. Tentu saja secara umum masyarakat Gampong Pango Raya Kecamatan Ulee Kareng Banda Aceh sangat mendukung perempuan yang ikut serta berkecimpung dalam dunia politik. Sebab menurut mereka, adanya perempuan yang ber-kecimpung dalam dunia politik akan sangat membantu kaum perempuan dalam menyuarakan aspirasi kaum perempuan lainnya. Selain untuk men-ambah wawasan perempuan itu sendiri, dengan adanya perempuan yang terlibat dalam dunia politik juga 
akan memper-lihatkan kesetaraan gender antara laki-laki dan perempuan. Sehingga tidak ada lagi perbedaan antara laki-laki dan perempuan dimata masyarakat. Apalagi kalau perempuan tersebut bisa membawa suatu perubahan bagi masyarakatnya.

2. Kendala-kendala yang menghambat perempuan ikut dalam berpolitik adalah bagi mereka yang sudah menikah tidak mendapatkan izin dari suami, tingkat pendidikan yang rendah, tidak adanya dukungan dari pihak keluarga maupun lingkungannya, kurang adanya kesempat-an, pandangan masyarakat yang tidak baik terhadap perempuan yang ikut berkecimpung dalam dunia politik serta rendahnya minat dari perempuan itu sendiri.

\section{Saran-Saran}

Atas dasar kesimpulan tersebut di atas, maka ada beberapa saran dari peneliti, yang diperuntukan kepada masyarakat Gampong Pango Raya Kecamatan Ulee Kareng Banda Aceh sebagai berikut:

a. Kepadatokoh perempuan yang mempunyai keinginan untuk ikut berkecimpung dalam dunia politik, agar dapat meningkatkan pengetahuan dan wawasannya terkait dengan bidang yang diminatinya, dan juga diharapkan kepada keluarga dapat men-dukung penuh anggota keluarganya yang punyai keinginan dalam dunia politik untuk membawa hasil yang positif.

b. Kepada pemerintah kiranya di masa yang akan datang lebih mendorong dan mem-perhatikan keterwakilan kaum perempuan dalam dunia politik, sebagaimana dalam pasal 75 UU No. 11 Tahun 2006 tentang Pemerintahan Aceh hal ini mendasari bahwa kaum perempuan dapat terlibat langsung dalam dunia politik dengan keterwakilan $30 \%$ dalam pendirian dan kepengurusan partai ditingkat pusat maupun ditingkat daerah.

\section{DAFTAR PUSTAKA}

Al Afghani, Sa'id, 2016, Pemimpin Wanita Di Kancah Politik, Surabaya: Pustaka Pelajar dan Pustaka LP2IF.

Asshiddiqie, Jimly, 2015. Konstitusi dan Ketatanegaraan
Indonesia
Kontemporer, Bekasi: The Biography Institute.

Azwar, Saifuddin, 2012, Prosedur Penelitian Suatu Praktek, Jakarta: Rineka Cipta. Basrowi,Dr. M.S, 2015, Pengantar Sosiologi, Ciawi-Bogor: Ghalian Indonesia.

Bodiarjdo, Mariam, 2016, Dasar-Dasar Ilmu Politik,Jakarta, PT. Gramedia Pustaka Utama.

Cangara, Hafied, Prof. Dr, M. Sc, 2014, KomunikasiPolitik, Jakarta: Rajawali Pers.

David E. After ,2012), Pengantar Analisis Politik. Jakarta: Rajawali.

Suzanne Infeld Keller, 2014, Penguasa dan Kelompok Elit: Peranan Elit Penentu Dalam Masyarakat Modern, Jakarta: Rajawali.

Duverger, Maurice, 2013, Sosiologi Politik, Jakarta, PT Raja Grafindo Persada.

Farida, Anik, dan Mulia, Siti Musdah, 2015, Perempuan dan Politik, Jakarta: Gramedia Pustaka Utama.

Jurnal Perempuan edisi 34 2014, Politik dan Keterwakilan Perempuan, Jakarat: Yayasan Jurnal Perempuan.

Kartika, Sofia 2016, Perempuan dan politik, Jakarta:Yayasan Jurnal Perempuan.

Katjasungkana, Nursyabani, 2011, Potret Perempuan: Tinjauan Politik, Ekonomi, Hukum, di Zaman Orde Baru, Yogyakarta: PSW Univ. Muhamadiyah dan Pustaka Pelajar.

Lexy J. Moelong. 2012. Metode Penelitian Kualitatif. Bandung: PT. Remaja Rosda Karya.

Maran, Rafael Raga, 2011, Pengantar Sosiologi Politik, Jakarta: PT. Rineka Cipta.

Murniati, Nunuk P, 2014, Getar Gender, Magelang: Indonesia Tera.

Noerdin, Edriana, 2015, Politik Identitas Perempuan Aceh, Jakarta: Women Research Institute.

Rush, Althoff, 2012, Sosiologi Politik, Jakarta: PT Raja Grafindo Persada.

Sutarti, Nurul, dkk, 2014, Menyibak Tabir Perempuan Berpolitik, Surakarta: Yayasan Krida Paramita Surakarta.

Widyani, Soetjipto, Ani, 2015, Politik Perempuan Bukan Gerhana; Jakarta: Kompas. 